\title{
Cognitive outcomes in late childhood and adolescence of neonatal hypoxic-ischemic encephalopathy
}

\author{
Bo Lyun Lee, MD, PhD ${ }^{1}$, Hannah C. Glass, MDCM, MAS ${ }^{2,3,4}$
}

${ }^{1}$ Department of Pediatrics, Inje University Busan Paik Hospital, Inje University College of Medicine, Busan, Korea; ${ }^{2}$ Department of Neurology and Weill Institute for Neurosciences, University of California San Francisco, San Francisco, CA, USA; ${ }^{3}$ Department of Pediatrics, Benioff Children's Hospital, University of California San Francisco, San Francisco, CA, USA; ${ }^{4}$ Department of Epidemiology and Biostatistics, University of California San Francisco, San Francisco, CA, USA

Hypoxic-ischemic encephalopathy (HIE) is the most common cause of neonatal encephalopathy with a global incidence of approximately 1 to 8 per 1,000 live births. Neonatal encephalopathy can cause neurodevelopmental and cognitive impairments in survivors of hypoxic-ischemic insults with and without functional motor deficits. Normal neurodevelopmental outcomes in early childhood do not preclude cognitive and behavioral difficulties in late childhood and adolescence because cognitive functions are not yet fully developed at this early age. Therapeutic hypothermia has been shown to significantly reduced death and severe disabilities in term newborns with HIE. However, children treated with hypothermia therapy remain at risk for cognitive impairments and follow-up is necessary throughout late childhood and adolescence. Novel adjunctive neuroprotective therapies combined with therapeutic hypothermia may enhance the survival and neurodevelopmental outcomes of infants with HIE. The extent and severity of brain injury on magnetic resonance imaging might predict neurodevelopmental outcomes and lead to targeted interven tions in children with a history of neonatal encephalopathy. We provide a summary of the long-term cognitive outcomes in late childhood and adolescence in children with a history of HIE and the association between pattern of brain injury and neurodevelopmental outcomes.

Key words: Hypoxic-ischemic encephalopathy, Neonatal encephalopathy, Brain magnetic resonance imaging, Cognition, Outcomes

\section{Key message}

- Cognitive impairments occur in children with hypoxic-ischemic encephalopathy (HIE) even without neuromotor deficits.

- Therapeutic hypothermia has improved neurodevelopmental outcomes of children with HIE; however, $40 \%$ of children remain at risk of death/disability or cognitive impairments necessitating the development of adjunctive neuroprotective therapies.
- Long-term follow-up until adolescence is required to identify cognitive dysfunction.

- A pattern of watershed injury on brain imaging is associated with poor cognitive outcomes.

\section{Introduction}

Neonatal encephalopathy is a clinical syndrome that presents with abnormal neurological function and is characterized by difficulty in maintaining respiration, decreased activity and level of consciousness, reduced motor tone, persistence of primitive reflexes, and seizures in term and late preterm newborns. ${ }^{1)} \mathrm{Hy}$. poxic-ischemic encephalopathy (HIE), which is defined as disturbed cerebral function due to lack of oxygen to the brain following antenatal/perinatal adverse events, is the most common cause of neonatal encephalopathy. ${ }^{2)}$ While several studies on cognitive outcomes of neonatal HIE excluded other obvious causes of neonatal encephalopathy, there is still paucity of data on the exact proportion of neonatal encephalopathy that is due to perinatal hypoxia or ischemia. This is because it is difficult to enroll only infants with HIE as neonatal encephalopathy is a heterogenous disorder with various antenatal or intrapartum risk factors that are not hypoxic or ischemic. ${ }^{2,3)}$ Since a large proportion of neonatal encephalopathy occurs after hypoxia-ischemia and most clinical studies on cognitive outcomes have focused on HIE, the authors in this article use the term neonatal encephalopathy to refer to brain injury after presumed neonatal hypoxiaischemia. ${ }^{1,3-6)}$

The global incidence of HIE varies between 1 and 8 per 1,000 live births. ${ }^{7-9)}$ In population-based studies performed in high-in. come countries, the incidence was between 1 and 2 per 1,000 live births. ${ }^{7-9)}$ Despite significant improvements in neonatal critical care over the last decade, HIE still results in adverse outcomes, including death, cerebral palsy, epilepsy, global developmental delay, and intellectual disability for many infants. ${ }^{4,8)}$ Of the various long-term morbidities, cognitive impairments, with or without motor deficits, are of significant concern because it

\footnotetext{
Corresponding author: Hannah C. Glass, MDCM, MAS, Departments of Neurology and Pediatrics, University of California San Francisco, 675 Nelson Rising Lane, Room 414C, Box 0663, San Francisco, CA, 94158, USA 
adversely affects future academic achievement and behavioral adjustment. ${ }^{3,4,10,11)}$

As development of specific cognitive functions continues throughout childhood, follow-up during school-going period is necessary to gain insight into the long-term neurocognitive outcomes of neonatal encephalopathy. $\left.{ }^{4}\right)$ Normal neurodevelopmental outcomes at 18 to 24 months after neonatal hypoxicischemic insult cannot exclude subtle cognitive and behavioral difficulties during school age because some cognitive functions that are not fully developed cannot be examined using neuropsy. chologic tests at this early age. ${ }^{4)}$ Moreover, subtle cognitive deficits may not become apparent until the child is asked to complete complex tasks. ${ }^{4)}$

In this article, we review the results of previously published studies on long-term cognitive outcomes from late childhood through adolescence, including neurodevelopmental outcome studies of therapeutic hypothermia and novel adjunctive therapies. We also describe the association between patterns of brain injury on neonatal magnetic resonance imaging (MRI) and longterm neurodevelopmental prognosis.

\section{Cognitive outcomes of neonatal encephalo- pathy prior to hypothermia therapy}

\section{Cognitive outcomes in late childhood (5-10 years)}

There is a strong relationship between severity of neonatal encephalopathy and neurodevelopmental outcomes. ${ }^{4,12,13)}$ In general, children with severe neonatal encephalopathy have a high likelihood of impaired neurodevelopment, whereas children who survive neonatal encephalopathy without motor disabilities or mild hypoxic-ischemic insult may have normal outcomes in early childhood. However, mild to moderate cognitive problems are common in survivors without functional motor deficits after perinatal hypoxic-ischemic insult and in children with a history of mild neonatal encephalopathy., ${ }^{5,14,15)}$ Several studies on cognitive outcomes of school-age children before onset of therapeutic hypothermia have been reported (Table 1).

Robertson and Finer ${ }^{12)}$ reported on cognitive functions, behavior problems, and learning difficulties in 127 school-going 5.5-year-old-nonimpaired survivors (children without cerebral palsy, seizures, blindness, hearing loss, or intelligence quotient (IQ) of $>3$ standard deviations below mean) after mild and moderate neonatal encephalopathy. They included an age-matched control group of term neonatal intensive care unit graduates without encephalopathy and a normal peer group. The authors showed that compared with normal children and those with mild encephalopathy, children with moderate encephalopathy had lower school readiness scores, including lower IQ scores and scores for quantitative language, auditory memory, letter recog. nition, and visuo-motor integration. All nonimpaired children with moderate encephalopathy scored approximately 10 points lower than those in the age-matched group. They also had increased episodes of explosiveness and irritability. ${ }^{6,12)}$ Robertson et al., ${ }^{13)}$ in a follow-up study, compared the school performance at 8 years of age of 145 children ( $75 \%$ from the original cohort) with that of 155 peer-group children. The children with moderate to severe encephalopathy had significantly lower IQ, visual-motor integration, and receptive vocabulary scores, as well as reading, spelling, and arithmetic grade levels than those of children in the mild encephalopathy or peer comparison groups. Nonimpaired survivors of moderate encephalopathy were similar to the healthy peer group on perceptual-motor skills and receptive language skills but appeared to be more than one grade level behind their age-matched peer group. The authors pointed out that children with moderate neonatal encephalopathy without motor disability had reduced school performance.

Marlow et al. ${ }^{14)}$ investigated neuropsychological and educational outcomes of 7-year-old-nondisabled children after neonatal encephalopathy. Intellectual functioning including overall cognitive ability was assessed using the British Ability Scales-II school-age battery. A neuropsychological assessment scale was used to examine the neuropsychological performance of children with acquired brain injury in 5 domains (attention/executive function, language, sensorimotor function, visuospatial processing, memory, and learning). Of the 50 children without motor disability, cognitive scores were lowest in children who had severe neonatal encephalopathy (mean difference in general cognitive ability from peers 11.3 points; $95 \%$ confidence interval [CI] 3.818.8). Memory and attention/executive functions were also impaired in the severe group. In the moderate encephalopathy group, cognitive profile was similar to that of the control group, but this group showed significantly lower language domain scores and poorer attainment levels of reading, spelling, and mathematics than those of the peer group. The authors concluded that learning difficulties at school age are common in children with a history of neonatal encephalopathy even in the absence of functional motor deficits, and comprehensive school assessment is needed for evaluating cognition, memory, and attention/executive functions.

Van Handel et al. ${ }^{16}$ also found impaired memory function in 9to 10-year-old children with a history of neonatal encephalopathy but did not have functional motor deficits. Children without motor deficits after moderate neonatal encephalopathy showed impaired maintenance and retrieval of information in verbal, visuospatial, and verbal associative long-term memory, and reduced speed of working memory processes, while those with mild neonatal encephalopathy demonstrated normal short-term and working memory functions, and slightly weakened verbal learning capacity. They also showed that children who had mild neonatal encephalopathy experienced more cognitive problems than healthy peers, and their performance was between that of controls and children with moderate encephalopathy.

\section{Cognitive outcomes in adolescence (11-18 years)}

Only a few studies have evaluated cognitive consequences of neonatal encephalopathy in adolescence (Table 1). Most studies have focused on cognitive outcomes of adolescents with a history 
Table 1. Cognitive outcomes in late childhood and adolescence before hypothermia therapy

\begin{tabular}{|c|c|c|c|c|c|}
\hline Study & $\begin{array}{l}\text { Median or } \\
\text { mean age } \\
(y r)\end{array}$ & $\begin{array}{l}\text { Study group } \\
\text { (n) }\end{array}$ & $\begin{array}{l}\text { Control group } \\
\text { (n) }\end{array}$ & Measurements & Findings \\
\hline \multicolumn{6}{|c|}{ Late childhood (5-10 yr) } \\
\hline $\begin{array}{l}\text { Robertson } \\
\text { and } \\
\text { Finer }^{12)} \\
(1988)\end{array}$ & 5.5 & $\begin{array}{l}127 \text { ( } 56 \text { With mild NE, } \\
\text { and } 71 \text { with mode- } \\
\text { rate NE) }\end{array}$ & $\begin{array}{l}\text { Neonatal compari- } \\
\text { son group }{ }^{\text {a): }} 71, \\
\text { peer comparison } \\
\text { group: } 188\end{array}$ & $\begin{array}{l}\text { Stanford-Binet Intelli- } \\
\text { gence Scale; accepted } \\
\text { norms are } 100 \pm 16\end{array}$ & $\begin{array}{l}\text { Moderate NE group had the lowest mean IQ score. } \\
\text { - Moderate NE: } 99 \pm 18^{\text {b) }} \\
\text { - Mild NE: } 106 \pm 12 \\
\text { - Neonatal comparison: } 105 \pm 15 \\
\text { - Peer comparison: } 108 \pm 14\end{array}$ \\
\hline $\begin{array}{l}\text { Robertson } \\
\text { et al. }{ }^{13)} \\
(1989)\end{array}$ & 8 & $\begin{array}{l}145 \text { (56 With mild NE, } \\
84 \text { with moderate } \\
N E \text {, and } 5 \text { with se- } \\
\text { vere NE) }\end{array}$ & $\begin{array}{l}\text { Peer comparison } \\
\text { group:155 }\end{array}$ & WISC-Revised (1974) & $\begin{array}{l}\text { Lower mean IQ score in moderate impaired and } \\
\text { nonimpaired NE group compared with those of the } \\
\text { mild NE and peer group. } \\
\text { - Moderate nonimpaired NE: } 102 \pm 17^{\text {b) }} \\
\text { - Moderate impaired NE: } 68 \pm 27^{\text {b) }} \\
\text { - Mild nonimpaired NE: } 106 \pm 13 \\
\text { - Control: } 112 \pm 13\end{array}$ \\
\hline $\begin{array}{l}\text { Marlow } \\
\text { et al }^{14)} \\
(2005)\end{array}$ & 7.2 & $\begin{array}{l}50 \text { (32 With mode- } \\
\text { rate } \mathrm{NE} \text {, and } 18 \text { with } \\
\text { severe NE) }\end{array}$ & $\begin{array}{l}\text { Peer comparison } \\
\text { group: } 49\end{array}$ & $\begin{array}{l}\text { British ability scales } \\
\text { (BAS-II) school-age } \\
\text { battery }\end{array}$ & $\begin{array}{l}\text { General cognitive ability scores were lowest in the } \\
\text { severe NE group for children without motor disability; } \\
\text { Peer and moderate groups had comparable scores. } \\
\text { - Severe NE: } 103 \pm 13^{b)} \\
\text { - Moderate NE: } 112 \pm 11 \\
\text { - Control: } 114 \pm 14\end{array}$ \\
\hline $\begin{array}{l}\text { van Kooij } \\
\text { et } \mathrm{al}^{15)} \\
(2010)\end{array}$ & 910 & $\begin{array}{l}80 \text { ( } 34 \text { With mild NE, } \\
\text { and } 46 \text { with mode- } \\
\text { rate NE) }\end{array}$ & $\begin{array}{l}\text { Age and sex ma- } \\
\text { tched group: } 52\end{array}$ & WISC-III (Dutch version) & $\begin{array}{l}\text { The mean estimated IQ score of children with moderate } \\
\text { and mild NE without cerebral palsy were lower than } \\
\text { that of the control group. } \\
\text { - Children with CP: } 70 \pm 18^{\text {b) }} \\
\text { - Moderate NE without CP: } 92 \pm 20^{\text {b) }} \\
\text { - Mild NE without CP: } 99 \pm 14^{\text {b) }} \\
\text { - Control: } 109 \pm 12\end{array}$ \\
\hline $\begin{array}{l}\text { van Handel } \\
\text { et } \mathrm{al}^{16)} \\
(2012)\end{array}$ & 9.9 & $\begin{array}{l}81 \text { ( } 32 \text { With mild NE, } \\
39 \text { with moderate } \\
N E \text {, and } 10 \text { with } C P \text { ) }\end{array}$ & $\begin{array}{l}\text { Peer comparison } \\
\text { group: } 53\end{array}$ & WISC-III (Dutch version) & $\begin{array}{l}\text { All group differences in mean estimated IQ score were } \\
\text { significant except between moderate NE mild NE. } \\
\text { - Children with CP: } 72 \pm 18^{b)} \\
\text { - Moderate NE: } 91 \pm 21^{\text {b) }} \\
\text { - Mild NE: } 99 \pm 14^{\text {b) }} \\
\text { - Control: } 109 \pm 12\end{array}$ \\
\hline \multicolumn{6}{|c|}{ Adolescence (11-18 yr) } \\
\hline $\begin{array}{l}\text { Gadian } \\
\text { et } \mathrm{al}^{17)} \\
(2000)\end{array}$ & 12.9 & $\begin{array}{l}5 \text { Without major neu- } \\
\text { rologic deficits }\end{array}$ & $\begin{array}{l}\text { Normal subjects: } \\
35\end{array}$ & $\begin{array}{l}\text { Wechsler Memory Scale } \\
\text { (Wechsler, 1945) }\end{array}$ & $\begin{array}{l}\text { All } 5 \text { patients showed severe impairments of episodic } \\
\text { memory (memory for events). } \\
\text { - Memory quotient (MQ) of patients with HIE: } 83.8 \pm 5.4 \\
\text { - MQ of normal subjects: } 105.8 \pm 13.9\end{array}$ \\
\hline $\begin{array}{l}\text { Mañeru } \\
\text { et al }^{18)} \\
(2001)\end{array}$ & 15.6 & $\begin{array}{l}28 \text { ( } 8 \text { With mild } N E \text {, } \\
\text { and } 20 \text { with mode- } \\
\text { rate NE) }\end{array}$ & $\begin{array}{l}\text { Matched healthy } \\
\text { adolescents: } 28\end{array}$ & $\begin{array}{l}\text { Rey's Auditory Verbal } \\
\text { Learning Test }\end{array}$ & $\begin{array}{l}\text { Participants with moderate NE showed decreased ability } \\
\text { of delayed recall. } \\
\text { - Moderate NE: } 11.5 \pm 1.9^{\text {b) }} \\
\text { - Mild NE: } 12.0 \pm 1.6 \\
\text { - Control: } 12.9 \pm 1.5\end{array}$ \\
\hline $\begin{array}{l}\text { Lindstrm } \\
\text { et al. }^{20)} \\
(2006)\end{array}$ & 16.8 & $\begin{array}{l}28 \text { With moderate NE } \\
\text { without CP }\end{array}$ & $\begin{array}{l}\text { Siblings of school } \\
\text { age: } 15\end{array}$ & WISC-III & $\begin{array}{l}\text { Study group had more cognitive dysfunction (low/ } \\
\text { borderline IQ and learning disability) compared to their } \\
\text { siblings. } \\
\text { - Moderate NE: } 20 / 28 \text { (71\%) } \\
\text { - Control: } 2 / 15(13 \%)\end{array}$ \\
\hline $\begin{array}{l}\text { Perez } \\
\text { et al. }{ }^{3)} \\
\text { (2013) }\end{array}$ & 11.2 & $\begin{array}{l}57 \text { Without } \mathrm{CP} \text { and } \\
\text { severe mental retar- } \\
\text { dation }\end{array}$ & None & $\begin{array}{l}\text { WISC-R (German ver- } \\
\text { sion) }\end{array}$ & $\begin{array}{l}\text { Full-scale and performance IQ scores were significantly } \\
\text { lower in study group than the population norms. } \\
\text { - Full-scale IQ mean score: } 95(62-120) \\
\text { - Verbal IQ mean score: } 98 \text { (63-123) } \\
\text { - Performance IQ mean score: } 95(66-118) \\
\text { - Full-scale IQ score < } 85: 14 / 57(25 \%)\end{array}$ \\
\hline 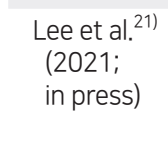 & 13 & 16 With NE & None & WISC-IV, V, and WASI-II & $\begin{array}{l}\text { Adolescents }(n=7) \text { with watershed pattern of injury had } \\
\text { lower the mean estimate of overall cognitive ability } \\
\text { than those }(n=7) \text { with normal imaging ( } 94 \pm 21 \text { vs. } 113 \\
\pm 9, P=0.04)\end{array}$ \\
\hline
\end{tabular}

Values are presented as mean \pm standard deviation.

$\mathrm{NE}$, neonatal encephalopathy; IQ, intelligence quotient; WISC, Wechsler Intelligence Scale for Children; CP, cerebral palsy; HIE, hypoxic-ischemic encephalopathy; WASI, Wechsler Abbreviated Scale of Intelligence.

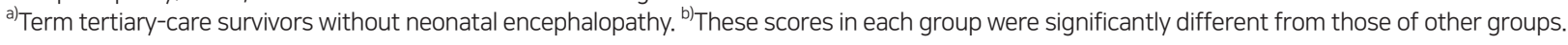


of mild or moderate neonatal encephalopathy but no motor deficits, and they reported that cognitive impairments in adolescence could be subtle but persistent and not apparent in early childhood. ${ }^{3,6,17-21)}$

Gadian et al. ${ }^{17)}$ studied 5 adolescent patients with a mean age of 13 years who had hypoxic-ischemic episodes at birth but whose developmental milestones were achieved at expected ages. All the adolescents had severe impairments of episodic memory that went unrecognized in early childhood. Hippocampal volume measurements using quantitative MRI techniques demonstrated bilateral hippocampal atrophy in all 5 cases. The authors suggested that while hypoxic-ischemic insults in these patients produced selective injury in bilateral hippocampus causing memory impairments, the insults were insufficient to result in severe cognitive deficits. These problems were found only following their entry to school.

A Spanish study by Mañeru et al. ${ }^{18)}$ reported neuropsychologic outcomes of adolescents after moderate perinatal asphyxia $(\mathrm{n}=$ 20 , mean age of 15.6 years) and compared them to that of an age-matched healthy group ( $n=28$, mean age of 16.8 years). They excluded patients with cerebral palsy, intellectual disability, or neuromotor deficits. This study showed that children with moderate perinatal asphyxia had significantly delayed recall on tests related to both verbal and visual information, decreased perceptual-motor speed and attention, and impaired executive functions. Conversely, children ( $\mathrm{n}=8$, mean age of 15.6 years) in the mild perinatal asphyxia group exhibited scores which were similar to those of the control group in all the assessed variables.

A diffusion tensor imaging study demonstrated white matter disturbances in adolescents with a history of moderate neonatal encephalopathy but no cerebral palsy. ${ }^{19)}$ Eight of the 9 participants had cognitive problems, mainly with memory and attention. Even in the absence of motor deficits, moderate neonatal encephalopathy caused long-term white matter changes that had not recovered by adolescence. One Swedish population-based study also assessed cognitive functions and behavior problems in teenagers aged 15-19 years who had survived moderate neonatal encephalopathy. ${ }^{20)}$ Out of 97,468 children born in Sweden in 1985, they enrolled 56 children who met the clinical criteria for moderate neonatal encephalopathy, who were born at term, and had an Apgar score of $<7$ at 5 minutes. Thirteen children's parents declined participation in this study. Of the 43 children who participated, 13 (30\%) had cerebral palsy, 22 (51\%) had cognitive dysfunction without cerebral palsy, and only 8 (19\%) had no obvious impairments.

Perez et al. ${ }^{3)}$ reported cognitive outcomes of 57 children without a major disability (cerebral palsy or intellectual disability). The children were examined at a median age of 11.2 years (range, 8.2-15.7 years) and showed lower full-scale and performance IQ scores compared with the population norms. The proportion of children with an IQ score lower than 85 was higher than expected at 24.6\% (expected proportion, 15.9\%). Motor performance testing using the Zurich Neuromotor Assessment was performed in 53 of the 57 children. Motor performance was below the expected norm of 0 in all components of pure motor, adaptive fine motor, associate movements, and gross motor domains. On multiple linear regression analysis, the higher watershed injury score correlated with poorer total IQ (4.9-point decrease in IQ score for each point in the watershed injury score, $P=0.01$ ). The authors suggested that neonatal encephalopathy without major disability increased the risk for long-term intellectual and motor impairments and that the severity of watershed injury was associated with the intellectual outcomes.

Our prospective cohort study recently reported serial longterm cognitive outcomes and follow-up brain MRI at the median age of 13 in adolescents who were admitted to the Intensive Care Nursery at the University of California, San Francisco from 1999 to 2008 due to neonatal HIE. ${ }^{21)}$ Sixteen children finally completed both MRI and neurocognitive testing as they reached adolescence. Seven children had a watershed predominant pattern of injury, 2 had a basal ganglia/thalamus predominant pattern, and 7 had normal MRI. Children with the watershed pattern of injury on neonatal imaging had lower overall cognitive abilities, especially in perceptual reasoning, and auditory working memory than those with normal imaging. The increasing severity of the watershed injury was significantly associated with decreasing overall cognitive abilities. The participants with comorbid diag. nosis of a postneonatal epilepsy and cerebral palsy showed the lowest cognition in this cohort.

\section{Cognitive outcomes at school age after hypothermia therapy}

Several randomized clinical trials and systemic review have demonstrated that therapeutic hypothermia for term newborns with moderate to severe HIE results in significant reduction in mortality or neurodevelopmental disability at the age of 18-24 months. ${ }^{22-29)}$ The current standard of care for full-term neonates (>36 weeks gestation) with moderate or severe neonatal encephalopathy is to apply hypothermia therapy within the first 6 hours after birth for 72 -hour duration to a depth of $33.0^{\circ} \mathrm{C}-$ $34.0^{\circ} \mathrm{C} .^{30)}$ Therapeutic hypothermia is administered either by selective head cooling with a head cap or whole-body systemic cooling using a blanket, followed by rewarming at a rate of $0.5^{\circ} \mathrm{C} / \mathrm{hr}$. Both protocols have demonstrated similar safety and effects regarding long-term neurological outcomes. Extending the duration of hypothermia and applying deeper cooling has not been shown to have any neuroprotective benefit. ${ }^{31)}$

However, there are a limited number of long-term follow-up clinical trials that have evaluated the sustained benefits of hypothermia therapy on cognitive outcomes until school age. . $^{10,32-34)}$ According to the CoolCap trial, cerebral hypothermia by selective head cooling in newborns with encephalopathy was shown to be beneficial in terms of death or severe disabilities at 18 months of age (odds ratio, $0.47 ; 95 \% \mathrm{CI}, 0.26-0.87 ; P=0.021) .{ }^{28)}$ The follow-up CoolCap study goal was to evaluate whether 18- to 22-month neurodevelopmental outcomes predicted functional 
outcomes at 7-8 years of age among surviving 62 children: 32 in the hypothermia group and 30 in the control group. ${ }^{34)}$ WeeFIM ratings were used to evaluate the functional development at school age. The measure consists of a set of ratings of 18 skills divided into 3 general domains: 8 of self-care (e.g., eating, dressing upper body), 5 of mobility (e.g., transfer to chair/wheelchair, walk), and 5 of cognition (comprehension, expression, social interaction, problem solving, and memory). ${ }^{34)}$ Caregivers are asked to rate a child about the functioning. The ratings are combined to yield 3 domain scores and a WeeFIM total. The baseline characteristics and 18-month primary outcomes data of the children with WeeFIM ratings at 6-7 years was not different from those of the children that were not assessed. There were no differences in the baseline characteristics of the study cohort. Favorable outcomes at 18 months were strongly associated with overall WeeFIM ratings within the normal range $(P=0.001)$, with a sensitivity of 0.87 and specificity of 0.56 . This study did not directly show the impact of hypothermia therapy due to insufficient power, but it supported the idea that this therapy had sustained treatment effect until school age.

In the National Institute of Child Health and Human Development (NICHD) trial, the authors studied the childhood outcomes at 6-7 years of age of 190 trial participants with moderate to severe encephalopathy (Table 2). ${ }^{32)}$ Baseline clinical characteristics including race, maternal education level, and intrapartum complications were similar between the 97 children in the hypothermia group and the 93 children in the control group except that mother of children in the hypothermia group had a higher incidence of antepartum hemorrhage. Forty-six children (47\%) in the hypothermia group and 58 (62\%) in the control group had the primary outcomes of death or an IQ score below 70 $(P=0.06) ; 38$ children (41\%) in the hypothermia group and 53 $(60 \%)$ in the control group had death or severe disability $(P=$ 0.03). Cognitive function in the nondisabled participants who could be examined by Developmental Neuropsychological Assessment revealed no significant differences in attention and executive function and visuospatial processing between the 2 groups. This long-term randomized trial indicated that wholebody hypothermia reduced death rate or severe disability in children at the age of 6-7 years (similar to the results at 18-22 months of age). In addition, hypothermia therapy did not increase the proportion of survivors with low cognitive function, even though the number of survivors was increased.

However, a second analysis study from the NICHD Neonatal Research Network indicated that hypothermia therapy did not completely prevent cognitive impairments. ${ }^{10)}$ Almost half of children treated with hypothermia therapy had IQ scores less than 85 and 22\% had IQ scores that were below 70, which was similar to the control group. Twenty percent of children with normal IQ scores after neonatal encephalopathy needed special educational assistance. Cognitive impairments resulting in IQ scores of less than 70 occurred without cerebral palsy in 9\% of children and borderline IQ scores ranging from 70 to 84 was seen in $31 \%$ survivors without cerebral palsy. Children with severe mental developmental impairments, less than 70 on the Mental Developmental Index, at 18 to 22 months continued to have severe cognitive impairments at school age. They also reported an association between maternal level of education of less than high school and lower IQ scores in all children in both the hypothermia and the control groups.

In the Total Body Hypothermia for Neonatal Encephalopathy (TOBY) trial, there was no significant difference in the primary outcomes of death or disability at 18 months between the hypothermia group and the control group. ${ }^{24)}$ However, hypothermia therapy reduced the risk of cerebral palsy, increased the rate of survival without neurologic disability, and improved mental and psychomotor outcomes compared with standard care. ${ }^{24)}$ The TOBY trial researchers conducted a follow-up study to evaluate

Table 2. Summary of 2 randomized clinical trial outcomes of late childhood (6 to 7 years of age) children after therapeutic hypothermia for neonatal hypoxic-ischemic encephalopathy

\begin{tabular}{|c|c|c|c|c|c|c|}
\hline \multirow{2}{*}{ Variable } & \multicolumn{3}{|c|}{ NICHD trial $(2012)^{29)}$} & \multicolumn{3}{|c|}{ TOBY trial $(2014)^{30)}$} \\
\hline & Hypothermia & Control & $P$ value & Hypothermia & Control & $P$ value \\
\hline Death, no./total no. (\%) & $27 / 97(28)$ & 41/93 (44) & 0.04 & 47/163 (29) & 49/162 (30) & 0.81 \\
\hline Death or IQ score <70, no./total no. (\%) & $46 / 97(47)$ & $58 / 93(62)$ & 0.06 & - & - & - \\
\hline IQ score $\geq 85$, no./total no. (\%) & - & - & - & $75 / 145(52)$ & $52 / 132(39)$ & 0.04 \\
\hline Death or severe disability, no./total no. (\%) & $38 / 93(41)$ & $53 / 89(60)$ & 0.03 & - & - & - \\
\hline Moderate or severe disability, no./survivors' total no. (\%) & 24/69 (35) & $19 / 50(38)$ & 0.87 & $21 / 96(22)$ & $31 / 83(37)$ & 0.03 \\
\hline Cerebral palsy, no./ survivors' total no. (\%) & $12 / 69(17)$ & $15 / 52(29)$ & 0.14 & $21 / 98(21)$ & $31 / 86(36)$ & 0.03 \\
\hline Survival free of disability, no./survivors' total no. (\%) & $28 / 69(41)$ & $21 / 50(42)$ & 0.87 & $65 / 96(68)$ & $37 / 83(45)$ & 0.002 \\
\hline Blindness, no./survivors' total no. (\%) & $1 / 67(1)$ & 2/50 (4) & 0.42 & $1 / 98(1)$ & $1 / 82(1)$ & 1.00 \\
\hline Hearing impairment, no./ survivors' total no. (\%) & $3 / 63(5)$ & $1 / 50(2)$ & 0.45 & $4 / 98(4)$ & $8 / 83(10)$ & 0.15 \\
\hline Full-scale IQ score, mean $\pm S D$ & $89.9 \pm 23.3$ & $75.3 \pm 24.4$ & 0.23 & $103.6 \pm 14.4$ & $98.5 \pm 18.9$ & 0.07 \\
\hline Verbal IQ score, mean \pm SD & $85.9 \pm 19.1$ & $86.4 \pm 13.7$ & 0.88 & $105.2 \pm 15.6$ & $101.1 \pm 17.3$ & 0.16 \\
\hline Performance IQ score, mean \pm SD & $91.3 \pm 17.3$ & $90.5 \pm 16.3$ & 0.82 & $101.1 \pm 15.0$ & $96.7 \pm 19.0$ & 0.12 \\
\hline Processing speed score, mean \pm SD & - & - & - & $98.7 \pm 12.4$ & $95.3 \pm 18.7$ & 0.22 \\
\hline
\end{tabular}

NICHD, National Institute of Child Health and Human Development; TOBY, Total Body Hypothermia for Neonatal Encephalopathy; IQ, intelligence quotient; $\mathrm{SD}$, standard deviation.

Boldface indicates a statistically significant difference with $P<0.05$. 
the long-term outcomes at 6 to 7 years of age (Table 2). ${ }^{33)}$ Parental level of education and socioeconomic status were similar in the hypothermia group and the control group in the TOBY trial on childhood outcomes. They used the Wechsler Preschool and Primary Scale of Intelligence III test or the Wechsler Intelligence Scale for Children IV assessment to evaluate general cognitive performance. Seventy-five of the 145 children (52\%) in the hypothermia group and 52 of 132 (39\%) in the control group showed the primary outcomes of survival with an IQ score of 85 or higher (relative risk, $1.31 ; 95 \% \mathrm{CI}, 1.01-1.71 ; P=0.04$ ). The frequency of survivors without neurologic abnormalities was 45\% (65 of 145 children) in the hypothermia group and 28\% (37 of 132 children) in the control group (relative risk, 1.60 ; $95 \%$ CI, 1.15 2.22; $P=0.002)$. More children in the hypothermia group than in the control group survived without neurologic abnormalities. The rate of cerebral palsy among survivors was lower in the hypothermia group than in the control group ( $21 \%$ vs. $36 \%, P=0.03)$. There were no significant differences between both groups in terms of parental assessments of health status and psychometric tests, except for attention-executive scores that were higher in the hypothermia group compared to those of the control group. The prevalence of use of special educational resources was also lower in the hypothermia group ( $8.2 \%$ vs. $26.9 \%$; relative risk, 0.30 ; $95 \%$ CI, $0.12-0.79 ; P=0.01)$, although the mean differences in the academic achievement score were not significant. This study provided evidence that neonatal therapeutic hypothermia for HIE continues to benefit the children until school age.

Table 2 shows the summary of neurodevelopmental deficits and cognitive outcomes after hypothermia therapy from the NICHD and TOBY trials. Both studies included information on parental education level and socioeconomic status that could be associated with cognitive development, and these were similar in the hypothermia and the control group. The mean IQ score of children with HIE may be poor because severely impaired participants could not complete IQ testing in these 2 studies. ${ }^{10,32,33)}$

\section{Adjunctive neuroprotective agents combined with hypothermia}

Therapeutic hypothermia alone is not sufficient to reduce the incidence of death and neurodevelopmental disabilities in child. hood and to prevent cognitive impairments at school age. ${ }^{10,22,35)}$ A meta-analysis showed that approximately $40 \%$ of infants that underwent hypothermia therapy either died or suffered significant long-term disabilities at 18 months. ${ }^{35,36)}$ Moreover, cognitive impairments remain critical concern for all children at the age of 6 to 7 years with a history of HIE. ${ }^{10)}$ Almost half of the children who received therapeutic hypothermia had IQ scores less than 85 , and a quarter had very low IQ scores less than $70.10,32,33)$ A large number of children still require additional therapies to further improve their cognitive outcomes after neonatal HIE. ${ }^{35)}$ Promising neuroprotective agents that could be used along with therapeutic hypothermia include erythropoietin, xenon, mela- tonin, stem cell, and antiseizure drugs. ${ }^{35,37-43)}$

Erythropoietin is a glycoprotein that is involved in erythropoiesis, but also has remarkable neuroprotective effects on endothelial cells, glial cells, and neurons in the central nervous system. 37,44) According to Neonatal Erythropoietin and Therapeutic Hypothermia Outcomes Phase II trial, treatment with erythropoietin along with hypothermia had better 12-month motor outcomes and less brain injury on MRI compared to hypothermia therapy alone. ${ }^{41)}$ Based on these findings, a phase III multicenter High-Dose Erythropoietin for Asphyxia and Encephalopathy study will assess the extent of brain injury using MRI and developmental status at 4, 8, 12, 18, and 24 months of age (clinical trial number, NCT02811263). ${ }^{43)}$ Another phase III study (clinical trial number, NCT01732146) by Patkai et al. (quoted from Rangarajan and Juul ${ }^{44)}$ ) that is ongoing, aims to evaluate the primary outcome of survival without neurological sequelae at 24 months of age. If these results are promising, longer-term follow-up studies up to school age will be necessary to define whether combined treatment with moderate hypothermia and erythropoietin has sustained effectiveness on neurological outcomes.

Xenon, a monoatomic gas that rapidly crosses the blood-brain barrier, inhibits $\mathrm{N}$-methyl-D-aspartate glutamate receptors; therefore, it could reduce neuronal injury and apoptosis caused by excessive glutamate concentration due to HIE. ${ }^{40)}$ The neuroprotective effect of xenon was shown to be promising in preclinical studies of HIE. ${ }^{45)}$ However, a multicenter phase II trial randomly assigning 92 newborns with moderate to severe HIE to either hypothermia plus xenon or hypothermia alone groups, did not show significant differences between magnetic resonance biomarkers of brain injury between both groups. Furthermore, long-term neurodevelopmental outcomes were not evaluated in that trial. ${ }^{37,40)}$ The current evidence is inadequate to determine the effectiveness of xenon therapy in combination with hypothermia and further trials on long-term outcomes are also necessary. ${ }^{46)}$ Melatonin, a neurohormone secreted by the pineal gland, has neuroprotective effects including antioxidant, anti-inflam. matory, and anti-apoptotic properties. ${ }^{47)}$ In a randomized controlled trial by Aly et al., ${ }^{39)}$ melatonin administration along with therapeutic hypothermia led to decreased frequency of seizures and less white matter abnormalities on MRI after 2 weeks of age in infants with HIE and improved survival without neurodevelopmental disabilities at 6 months of age compared to hypothermia therapy alone. Table 3 shows a summary of clinical studies on several neuroprotective agents along with hypothermia therapy for neonatal HIE. However, there have been no studies on longterm cognitive outcomes in these adjunctive therapies. Further studies are needed to define which safe and effective treatments along with therapeutic hypothermia could be applied to improve cognitive outcomes in children with neonatal HIE. 
Table 3. Clinical studies on neurodevelopmental outcomes after the administration of neuroprotective agents in combination with therapeutic hypothermia

\begin{tabular}{|c|c|c|c|c|c|}
\hline $\begin{array}{l}\text { Neuroprotective } \\
\text { agents }\end{array}$ & Study & Study group (n) & Control group (n) & Protocol & Findings \\
\hline \multirow[t]{3}{*}{ Epo } & $\begin{array}{l}\text { Wu et al. }{ }^{41)} \\
(2016)\end{array}$ & $\begin{array}{l}24 \text { (Epo 1,000 U/kg } \\
\text { intravenously plus } \\
\text { hypothermia) }\end{array}$ & $\begin{array}{l}26 \text { (saline plus } \\
\text { hypothermia) }\end{array}$ & $\begin{array}{l}\text { Epo at 1, 2, 3, 5, and } 7 \text { days of age } \\
\text { with hypothermia started within } 6 \\
\text { hr of birth, for } 72 \mathrm{hr}\end{array}$ & $\begin{array}{l}\text { Brain MRI at mean } 5.1 \text { days showed } \\
\text { significant lower brain injury score in } \\
\text { Epo group; and better motor outcome } \\
\text { at mean age } 12.7 \text { mo }\end{array}$ \\
\hline & $\begin{array}{l}\text { Juul et al. } \\
\text { (2018) }\end{array}$ & $\begin{array}{l}\text { Enrolling } 500 \text { (Epo } \\
1,000 \mathrm{U} / \mathrm{kg} \text { intra- } \\
\text { venously plus hypo- } \\
\text { thermia) }\end{array}$ & $\begin{array}{l}\text { Recruiting (sa- } \\
\text { line plus hypo- } \\
\text { thermia) }\end{array}$ & $\begin{array}{l}\text { Epo at 1, 2, 3, 5, and } 7 \text { days of age } \\
\text { with hypothermia started within } 6 \\
\text { hr of birth, for } 72 \mathrm{hr}\end{array}$ & $\begin{array}{l}\text { Ongoing study: evaluation of neurode- } \\
\text { velopmental outcomes and mortality } \\
\text { up to } 24 \text { mo }\end{array}$ \\
\hline & $\begin{array}{l}\text { Patkai et } \\
\text { al. }^{44), a)} \\
(2014)\end{array}$ & $\begin{array}{l}\text { Enrolling } 120 \text { (Epo } \\
1,000 \text { to } 1,500 \mathrm{U} / \mathrm{kg} \\
\text { intravenously plus } \\
\text { hypothermia) }\end{array}$ & $\begin{array}{l}\text { Recruiting (sa- } \\
\text { line plus hypo- } \\
\text { thermia) }\end{array}$ & $\begin{array}{l}\text { Epo at day } 1 \text { (at }<12 \text { hr), } 2 \text { and } 3 \\
\text { every } 24 \mathrm{hr} \text { ) with hypothermia } \\
\text { started within } 6 \text { hr of birth, for } 72 \\
\text { hr }\end{array}$ & $\begin{array}{l}\text { Ongoing study: evaluation of survival } \\
\text { without neurologic sequelae at } 24 \text { mo }\end{array}$ \\
\hline Xenon & $\begin{array}{l}\text { Azzopardi } \\
\text { et al. }{ }^{40)} \\
(2016)\end{array}$ & $\begin{array}{l}46 \text { ( } 30 \% \text { inhaled } \\
\text { xenon plus hypo- } \\
\text { thermia) }\end{array}$ & $\begin{array}{l}46 \text { (hypothermia } \\
\text { alone) }\end{array}$ & $\begin{array}{l}\text { Hypothermia in combination with } \\
30 \% \text { inhaled xenon for } 24 \mathrm{hr} \\
\text { commenced a median of } 10 \mathrm{hr} \\
\text { after birth }\end{array}$ & $\begin{array}{l}\text { No reduction in lactate to N-acetyl as- } \\
\text { partate ratio in the thalamus in MRI/ } \\
\text { MRS; administration of xenon was safe } \\
\text { but did not enhance the neuroprotec- } \\
\text { tive effect of hypothermia }\end{array}$ \\
\hline Melatonin & $\begin{array}{l}{\text { Aly et } a .^{39)}}_{(2014)}\end{array}$ & $\begin{array}{l}15 \text { (melatonin } 10 \mathrm{mg} / \\
\mathrm{kg} \text { plus hypother- } \\
\mathrm{mia} \text { ) }\end{array}$ & $\begin{array}{l}15 \text { (hypothermia } \\
\text { alone) }\end{array}$ & $\begin{array}{l}\text { Melatonin } 10 \mathrm{mg} / \mathrm{kg} \text { daily for a total } \\
\text { of } 5 \text { enteral doses with hypother- } \\
\text { mia }\end{array}$ & $\begin{array}{l}\text { Melatonin/hypothermia group had fewer } \\
\text { seizures, fewer white matter abnor- } \\
\text { malities on MRI and better mortality } \\
\text { rate at } 6 \text { months without neurode- } \\
\text { velopmental abnormalities }\end{array}$ \\
\hline Stem cell & $\begin{array}{l}\text { Cotten } \\
\text { et al. }^{38)} \\
(2014)\end{array}$ & $\begin{array}{l}23 \text { (fresh autologous } \\
\text { UCB cell plus hypo- } \\
\text { thermia) }\end{array}$ & $\begin{array}{l}82 \text { (hypothermia } \\
\text { alone) }\end{array}$ & $\begin{array}{l}\text { Infusion of } 4 \text { doses of UCB, } 1-5 \times 10^{7} \\
\text { cells/dose (the first dose after } \\
\text { birth, and at } 24,48 \text {, and } 72 \text { post- } \\
\text { natal hours) with hypothermia }\end{array}$ & $\begin{array}{l}\text { UCB cell administration with hypothermia } \\
\text { therapy was safe but did not provide } \\
\text { long-term neurodevelopmental outcomes } \\
\text { at } 12 \mathrm{mo}\end{array}$ \\
\hline Topiramate & $\begin{array}{l}\text { Filippi } \\
\text { et al. }^{42)} \\
(2018)\end{array}$ & $\begin{array}{l}21 \text { (topiramate plus } \\
\text { hypothermia) }\end{array}$ & $\begin{array}{l}23 \text { (hypothermia } \\
\text { alone) }\end{array}$ & $\begin{array}{l}\text { Topiramate administration by oro- } \\
\text { gastric tube, at the dosage of } 10 \\
\mathrm{mg} / \mathrm{kg} / \mathrm{day} \text { at } 1,2 \text {, and } 3 \text { days of } \\
\text { age with hypothermia }\end{array}$ & $\begin{array}{l}\text { Topiramate was safe but did not reduce } \\
\text { the combined frequency of mortality } \\
\text { and severe neurological disabilities at } \\
18-24 \text { mo }\end{array}$ \\
\hline
\end{tabular}

Epo, erythropoietin; MRI, magnetic resonance imaging; MRS, magnetic resonance spectroscopy; UCB, umbilical cord blood.

a) Quoted from Rangarajan and Juul. ${ }^{44}$

\section{Prognostic value of brain MRI injury patterns for cognitive outcomes}

Neonatal brain MRI is an important tool in the diagnostic evaluation and prognostication of newborn with HIE. ${ }^{48)} \mathrm{Al}$ though the risk of abnormal neurodevelopmental outcomes increases with the severity of brain injury, the risk can be affected by the pattern of injury. ${ }^{3,49,50)}$ Barkovich et al. developed an MRI scoring system to evaluate the severity and the pattern of neonatal brain injury, which is predictive of neurodevelopmental outcomes (Table 4). ${ }^{49,51)}$ Brain MRI in newborns with HIE shows 2 major patterns of injury: (1) a watershed predominant pattern involving white matter in the vascular watershed zone and cortical gray matter when severe, and (2) a basal ganglia/thalamus predominant pattern involving deep gray nuclei, hippocampi, and perirolandic area extending to the total cortex when severe (Fig. 1). ${ }^{49,51)}$ The pattern of injury can result in developmental impairments of different brain domains. ${ }^{11,49,50)}$ The basal ganglia/thalamus predominant pattern was more frequently associated with more severely impaired motor and cognition outcomes than the watershed injury pattern was. ${ }^{49,52,53)}$ The children with watershed predominant pattern primarily had cognitive impairments in the absence of functional motor deficit, although the newborns with the watershed predominant pattern had better neuromotor out-
Table 4 . Scoring systems according to the pattern of brain injury ${ }^{50,51)}$

\begin{tabular}{cl}
\hline Score & \multicolumn{1}{c}{ Finding } \\
\hline Watershed distribution \\
0 & Normal \\
1 & Single focal infarction \\
2 & Abnormal signal in anterior or posterior watershed white matter \\
3 & Abnormal signal in anterior or posterior watershed cortex and \\
& white matter \\
4 & Abnormal signal in both anterior and posterior watershed zones \\
5 & More extensive cortical involvement \\
Basal ganglia/thalamus distribution \\
0 & Normal or isolated focal cortical infarct \\
1 & Abnormal signal in thalamus \\
2 & Abnormal signal in thalamus and lentiform nucleus \\
3 & Abnormal signal in thalamus, lentiform nucleus, and perirolandic \\
4 & cortex \\
\hline
\end{tabular}

comes than those of newborns with basal ganglia injury pattern. ${ }^{6,49)}$

Children with moderate to severe brain lesions on neonatal or childhood MRI related with neonatal encephalopathy frequently have adverse motor and cognitive outcomes. ${ }^{15)}$ Van Kooij et al. ${ }^{15)}$ enrolled 80 children at the age of 9-10 years with a history of 


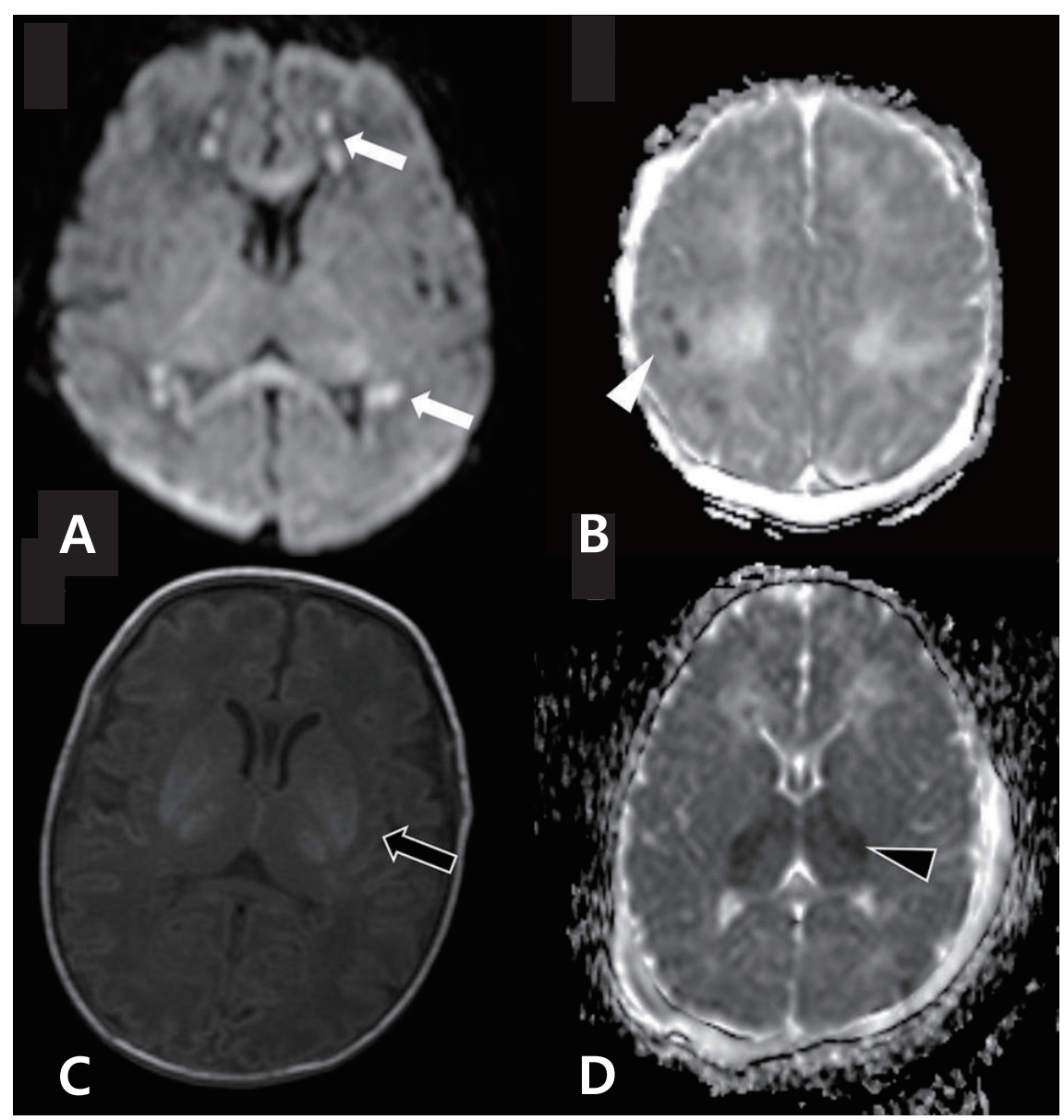

Fig. 1. Two major patterns of neonatal hypoxic-ischemic brain injury; the watershed predominant pattern (A, B) and basal ganglia/thalamus predominant pattern (C, D). (A) Axial diffusionweighted magnetic resonance imaging (MRI) of neonatal brain demonstrates reduced diffusion in periventricular white matter and corpus callosum (white arrows). (B) Apparent diffusion coefficient map of brain MRI shows hypointensity of multifocal areas in right parietal area (white arrowhead). (C) Moderately increased T1 hyperintensity involving the ventral lateral thalamus, posterior putamen, and globus pallidus (black arrow) can be seen. (D) Apparent diffusion coefficient map shows involvement of the bilateral thalamus (black arrowhead).

mild $(n=34)$ or moderate $(n=46)$ neonatal encephalopathy to assess the association between pattern of brain injury on neonatal and childhood MRI and long-term cognitive outcomes. The MRI findings were categorized into 3 grades: (1) no injury; (2) mild injury (white matter lesions); and (3) moderate to severe injury (watershed injury, basal ganglia/thalamus injury, and focal infarction). Neonatal and childhood MRIs were performed in 33 children; there was a good association between location and injury pattern between scans taken at these 2 time periods. Child. ren with moderate/severe lesions on MRIs had significantly higher frequency of total impairments score of $\leq 15$ th percentile on the Movement Assessment Battery for Children test and an IQ score of $\leq 85$ on the Wechsler Intelligence Scale for Children III compared with those with no injury and mild injury. According to a recent meta-analysis of studies with $\geq 35$-week-old neonates with HIE who underwent brain MRI and neurodeve. lopment follow-up for at least 12 months, an abnormal brain MRI was more frequent among patients with unfavorable neurodevelopmental outcomes than among those with favorable outcomes (odd ratio, 18.2; 95\% CI, 9.4-34.9; $P<0.0001$ ). ${ }^{48)}$
The prognostic value of neonatal brain MRI was high in moderate and severe HIE, and therapeutic hypothermia has not changed the value of brain MRI as a biomarker of neurodevelopmental outcomes beyond early infancy. ${ }^{48)}$

Steinman et al. ${ }^{50)}$ examined the association between MRI patterns of brain injury in neonatal encephalopathy secondary to hypoxia-ischemia and verbal and nonverbal cognitive outcomes using Wechsler Preschool and Primary Scale of Intelligence Revised in 64 children without functional impairments. In this prospective study, increasing severity of watershed injury on MRI was independently correlated with increased impairments of verbal abilities. ${ }^{50)}$ These findings provide evidence that the white matter and cortical injury seen in the watershed injury pattern has a negative effect on development of domain-specific cognitive function. The same group recently enrolled 32 children with neonatal encephalopathy due to hypoxic-ischemic insult, performed brain MRI to get deformation-based morphometry at 6 months, and assessed neurodevelopmental outcomes by Bayley Scales of Infant and Toddler Development-III at 30 months of age. ${ }^{11)}$ Therapeutic hypothermia was performed on 
29/32 neonates (91\%). They found that regional brain volume changes of perisylvian gray and white matter at 6 months were significantly associated with language outcomes. ${ }^{11)}$ Language development can be vulnerable to disruption even when injuries do not result in global cognitive deficits or cerebral palsy. ${ }^{11)}$ Followup long-term cohort study conducted at the same institution, and reported that children with the watershed injury could have problems in their overall cognition including perceptual reasoning skills and auditory working memory in adolescence. ${ }^{21)}$ Although cognitive problems may not always be definite during early childhood, this study suggested that differences in cognitive ability during adolescence might be related to early language vulnerability seen in children with the watershed injury. Perez et $\mathrm{al}^{3)}$ also demonstrated that the watershed injury pattern on neonatal MRI was associated with full-scale and verbal IQ scores in prospectively enrolled children with a mean age of 11.2 years and a history of HIE without major disabilities. They proposed that the severity of the watershed injury was correlated with lateterm intellectual performance, which could affect intelligence in adolescence.

Children with a watershed predominant pattern of injury seldom have severe motor deficits and are often considered to show normal early developmental outcomes until the age of 24 months. ${ }^{54,55)}$ However, when assessed at school age, some of these children present with cognitive impairments. ${ }^{54)}$ This could be because cognitive function related to the frontal lobe requires the maturation of white matter and posterior cortical regions, which usually occurs after the age of 12 years. ${ }^{18)}$ Therefore, longterm follow-up is needed to assess cognitive outcomes.

\section{Conclusion}

Children with a history of HIE are at risk for cognitive and executive function difficulties regardless of motor impairments in their late childhood and adolescence. It is important to monitor their intellectual function beyond infancy because cognitive dysfunction and memory impairments could be subtle or not apparent in early childhood but may cause difficulties later in childhood and adolescence. Continued surveillance could allow early detection of children with cognitive problems, allowing for appropriate interventions at an earlier age and give the children a chance to get extra educational assessment and teaching support. Therapeutic hypothermia lessens brain injury in newborns with HIE and has persistent neuroprotective effects until late childhood. However, therapeutic hypothermia should be combined with other neuroprotective agents to prevent or reverse brain injury as therapeutic hypothermia is not a comprehensive solution to prevent neurodevelopmental disabilities or cognitive impairments. Moreover, long-term follow-up studies are necessary to determine whether the improved cognitive outcomes will persist in adolescence. Children with the watershed injury on brain MRI should be carefully followed-up to assess cognitive function, especially language development even if overt neuromotor im- pairments are not presented.

See the commentary on "Cognitive outcomes in late childhood and adolescence of neonatal hypoxic-ischemic encephalopathy" via https://doi.org/10.3345/cep.2021.00822.

\section{Footnote}

Conflicts of interest: No potential conflict of interest relevant to this article was reported.

ORCID:

Bo Lyun Lee $\odot$ https://orcid.org/0000-0002-4758-6251

Hannah C. Glass $@$ https://orcid.org/0000-0002-3879-1966

\section{References}

1. McIntyre S, Badawi N, Blair E, Nelson KB. Does aetiology of neonatal encephalopathy and hypoxic-ischaemic encephalopathy influence the outcome of treatment? Dev Med Child Neurol 2015;57 Suppl 3:2-7.

2. Glass HC. Hypoxic-ischemic encephalopathy and other neonatal encephalopathies. Continuum (Minneap Minn) 2018;24:57-71.

3. Perez A, Ritter S, Brotschi B, Werner H, Caflisch J, Martin E, et al. Longterm neurodevelopmental outcome with hypoxic-ischemic encephalopathy. J Pediatr 2013;163:454-9.

4. van Handel M, Swaab H, de Vries LS, Jongmans MJ. Long-term cognitive and behavioral consequences of neonatal encephalopathy following perinatal asphyxia: a review. Eur J Pediatr 2007;166:645-54.

5. de Vries LS, Jongmans MJ. Long-term outcome after neonatal hypoxicischaemic encephalopathy. Arch Dis Child Fetal Neonatal Ed 2010;95: F220-4.

6. Pappas A, Korzeniewski SJ. Long-term cognitive outcomes of birth asphy. xia and the contribution of identified perinatal asphyxia to cerebral palsy. Clin Perinatol 2016;43:559-72.

7. Pierrat V, Haouari N, Liska A, Thomas D, Subtil D, Truffert P. Prevalence, causes, and outcome at 2 years of age of newborn encephalopathy: population based study. Arch Dis Child Fetal Neonatal Ed 2005;90:F257-61.

8. Kurinczuk JJ, White-Koning M, Badawi N. Epidemiology of neonatal encephalopathy and hypoxic-ischaemic encephalopathy. Early Hum Dev 2010;86:329-38.

9. Debillon T, BednarekN,Ego A, LyTONEPAL Writing Group. LyTONEPAL: long term outcome of neonatal hypoxic encephalopathy in the era of neuroprotective treatment with hypothermia: a French population-based cohort. BMC Pediatr 2018;18:255.

10. Pappas A, Shankaran S, McDonald SA, Vohr BR, Hintz SR, Ehrenkranz RA, et al. Cognitive outcomes after neonatal encephalopathy. Pediatrics 2015;135:e624-34.

11. Shapiro KA, Kim H, Mandelli ML, Rogers EE, Gano D, Ferriero DM, et al. Early changes in brain structure correlate with language outcomes in children with neonatal encephalopathy. Neuroimage Clin 2017;15:57280 .

12. Robertson CM, Finer NN. Educational readiness of survivors of neonatal encephalopathy associated with birth asphyxia at term. J Dev Behav Pediatr 1988;9:298-306.

13. Robertson CM, Finer NN, Grace MGA. School performance of survivors of neonatal encephalopathy associated with birth asphyxia at term. J Pediatr 1989;114:753-60.

14. Marlow N, Rose AS, Rands CE, Draper ES. Neuropsychological and educational problems at school age associated with neonatal encephalopathy. Arch Dis Child Fetal Neonatal Ed 2005;90:F380-7. 
15. van Kooij BJM, van Handel M, Nievelstein RAJ, Groenendaal F, Jongmans MJ, de Vries LS. Serial MRI and neurodevelopmental outcome in 9- to 10-year-old children with neonatal encephalopathy. J Pediatr 2010;157: 221-7.

16. van Handel M, de Sonneville L, de Vries LS, Jongmans MJ, Swaab H. Specific memory impairment following neonatal encephalopathy in termborn children. Dev Neuropsychol 2012;37:30-50.

17. Gadian DG, Aicardi J, Watkins KE, Porter DA, Mishkin M, Vargha-Khadem F. Developmental amnesia associated with early hypoxic-ischaemic injury. Brain 2000;123(Pt 3):499-507.

18. Mañeru C, Junqué C, Botet F, Tallada M, Guardia J. Neuropsychological long-term sequelae of perinatal asphyxia. Brain Inj 2001;15:1029-39.

19. Nagy Z, Lindström K, Westerberg H, Skare S, Andersson J, Hallberg B, et al. Diffusion tensor imaging on teenagers, born at term with moderate hypoxic-ischemic encephalopathy. Pediatr Res 2005;58:936-40.

20. Lindström K, Lagerroos P, Gillberg C, Fernell E. Teenage outcome after being born at term with moderate neonatal encephalopathy. Pediatr Neurol 2006;35:268-74.

21. Lee B, Gano G, Rogers EE, Xu D, Cox S, Barkovich AJ, et al. Long-term cognitive outcomes in term newborns with watershed injury caused by neonatal encephalopathy. Pediatr Res Forthcoming 2021.

22. Jacobs SE, Berg M, Hunt R, Tarnow-Mordi WO, Inder TE, Davis PG. Cooling for newborns with hypoxic ischaemic encephalopathy. Cochrane Database Syst Rev 2013;2013:Cd003311.

23. Shankaran S, Laptook AR, Ehrenkranz RA, Tyson JE, McDonald SA, Donovan EF, et al. Whole-body hypothermia for neonates with hypoxicischemic encephalopathy. NEngl J Med 2005;353:1574-84.

24. Azzopardi DV, Strohm B, Edwards AD, Dyet L, Halliday HL, Juszczak E, et al. Moderate hypothermia to treat perinatal asphyxial encephalopathy. NEngl J Med 2009;361:1349-58.

25. Edwards AD, Brocklehurst P, Gunn AJ, Halliday H, Juszczak E, Levene $\mathrm{M}$, et al. Neurological outcomes at 18 months of age after moderate hy. pothermia for perinatal hypoxic ischaemic encephalopathy: synthesis and meta-analysis of trial data. BMJ 2010;340:c363.

26. Zhou WH, Cheng GQ, Shao XM, Liu XZ, Shan RB, Zhuang DY, et al. Selective head cooling with mild systemic hypothermia after neonatal hypoxic-ischemic encephalopathy: a multicenter randomized controlled trial in China. J Pediatr 2010;157:367-72.

27. Jacobs SE, Morley CJ, Inder TE, Stewart MJ, Smith KR, McNamara PJ, et al. Whole-body hypothermia for term and near-term newborns with hypoxic-ischemic encephalopathy: a randomized controlled trial. Arch Pediatr Adolesc Med 2011;165:692-700.

28. Gluckman PD, Wyatt JS, Azzopardi D, Ballard R, Edwards AD, Ferriero $\mathrm{DM}$, et al. Selective head cooling with mild systemic hypothermia after neonatal encephalopathy: multicentre randomised trial. Lancet 2005; 365:663-70.

29. Simbruner G, Mittal RA, Rohlmann F, Muche R. Systemic hypothermia after neonatal encephalopathy: outcomes of neo.nEURO.network RCT. Pediatrics 2010;126:e771-8.

30. Papile LA, Baley JE, Benitz W, Cummings J, Carlo WA, Eichenwald E, et al. Hypothermia and neonatal encephalopathy. Pediatrics 2014;133:114650.

31. Shankaran S, Laptook AR, Pappas A, McDonald SA, Das A, Tyson JE, et al. Effect of depth and duration of cooling on deaths in the NICU among neonates with hypoxic ischemic encephalopathy: a randomized clinical trial. JAMA 2014;312:2629-39.

32. hankaran S, Pappas A, McDonald SA, Vohr BR, Hintz SR, Yolton K, et al. Childhood outcomes after hypothermia for neonatal encephalopathy. $\mathrm{N}$ Engl J Med 2012;366:2085-92.

33. Azzopardi D, Strohm B, Marlow N, Brocklehurst P, Deierl A, Eddama $\mathrm{O}$, et al. Effects of hypothermia for perinatal asphyxia on childhood outcomes. NEngl J Med 2014;371:140-9.

34. Guillet R, Edwards AD, Thoresen M, Ferriero DM, Gluckman PD, Whitelaw A, et al. Seven- to eight-year follow-up of the CoolCap trial of head cooling for neonatal encephalopathy. Pediatr Res 2012;71:205-9.

35. Oorschot DE, Sizemore RJ, Amer AR. Treatment of neonatal hypoxicischemic encephalopathy with erythropoietin alone, and erythropoietin combined with hypothermia: history, current status, and future research. Int J Mol Sci 2020;21;1487.

36. Tagin MA, Woolcott CG, Vincer MJ, Whyte RK, Stinson DA. Hypothermia for neonatal hypoxic ischemic encephalopathy: an updated systematic review and meta-analysis. Arch Pediatr Adolesc Med 2012;166:558-66.

37. McAdams RM, Juul SE. Neonatal encephalopathy: update on therapeutic hypothermia and other novel therapeutics. Clin Perinatol 2016;43:485500 .

38. Cotten CM, Murtha AP, Goldberg RN, Grotegut CA, Smith PB, Goldstein RF, et al. Feasibility of autologous cord blood cells for infants with hypoxicischemic encephalopathy. J Pediatr 2014;164:973-9.

39. Aly H, Elmahdy H, El-Dib M, Rowisha M, Awny M, El-Gohary T, et al. Melatonin use for neuroprotection in perinatal asphyxia: a randomized controlled pilot study. J Perinatol 2015;35:186-91.

40. Azzopardi D, Robertson NJ, Bainbridge A, Cady E, Charles-Edwards G, Deierl A, et al. Moderate hypothermia within $6 \mathrm{~h}$ of birth plus inhaled xenon versus moderate hypothermia alone after birth asphyxia (TOBY$\mathrm{Xe}$ ): a proof-of-concept, open-label, randomised controlled trial. Lancet Neurol 2016;15:145-53.

41. Wu YW, Mathur AM, Chang T, McKinstry RC, Mulkey SB, Mayock DE, et al. High-dose erythropoietin and hypothermia for hypoxic-ischemic encephalopathy: a phase II trial. Pediatrics 2016;137:e20160191.

42. Filippi L, Fiorini P, Catarzi S, Berti E, Padrini L, Landucci E, et al. Safety and efficacy of topiramate in neonates with hypoxic ischemic encephalopathy treated with hypothermia (NeoNATI): a feasibility study. J Matern Fetal Neonatal Med 2018;31:973-80.

43. Juul SE, Comstock BA, Heagerty PJ, Mayock DE, Goodman AM, Hauge $S$, et al. High-dose erythropoietin for asphyxia and encephalopathy (HEAL): a randomized controlled trial - background, aims, and study protocol. Neonatology 2018;113:331-8.

44. Rangarajan V, Juul SE. Erythropoietin: emerging role of erythropoietin in neonatal neuroprotection. Pediatr Neurol 2014;51:481-8.

45. Lobo N, Yang B, Rizvi M, Ma D. Hypothermia and xenon: novel noble guardians in hypoxic-ischemic encephalopathy? J Neurosci Res 2013;91: 473-8.

46. Rüegger CM, Davis PG, Cheong JL. Xenon as an adjuvant to therapeutic hypothermia in near-term and term newborns with hypoxic-ischaemic encephalopathy. Cochrane Database Syst Rev 2018;8:Cd012753.

47. Alonso-Alconada D, Álvarez A, Arteaga O, Martínez-Ibargüen A, Hilario E. Neuroprotective effect of melatonin: a novel therapy against perinatal hypoxia-ischemia. Int J Mol Sci 2013;14:9379-95.

48. Sanchez Fernandez I, Morales-Quezada JL, Law S, Kim P. Prognostic value of brain magnetic resonance imaging in neonatal hypoxic-ischemic encephalopathy: a meta-analysis. J Child Neurol 2017;32:1065-73.

49. Miller SP, Ramaswamy V, Michelson D, Barkovich AJ, Holshouser B, Wycliffe N, et al. Patterns of brain injury in term neonatal encephalopathy. J Pediatr 2005;146:453-60.

50. Steinman KJ, Gorno-Tempini ML, Glidden DV, Kramer JH, Miller SP, Barkovich AJ, et al. Neonatal watershed brain injury on magnetic resonance imaging correlates with verbal IQ at 4 years. Pediatrics 2009;123:102530.

51. Barkovich AJ, Hajnal BL, Vigneron D, Sola A, Partridge JC, Allen F, et al. Prediction of neuromotor outcome in perinatal asphyxia: evaluation of MR scoring systems. AJNR Am J Neuroradiol 1998;19:143-9.

52. Kaufman SA, Miller SP, Ferriero DM, Glidden DH, Barkovich AJ, Partridge JC. Encephalopathy as a predictor of magnetic resonance imaging abnormalities in asphyxiated newborns. Pediatr Neurol 2003;28:342-6.

53. Roland EH, Poskitt K, Rodriguez E, Lupton BA, Hill A. Perinatal hypoxicischemic thalamic injury: clinical features and neuroimaging. Ann Neurol 1998;44:161-6.

54. Barnett A, Mercuri E, Rutherford M, Haataja L, Frisone MF, Henderson S, et al. Neurological and perceptual-motor outcome at $5-6$ years of age in children with neonatal encephalopathy: relationship with neonatal brain MRI. Neuropediatrics 2002;33:242-8.

55. de Vries LS, Cowan FM. Evolving understanding of hypoxic-ischemic encephalopathy in the term infant. Semin Pediatr Neurol 2009;16:216-25. 
How to cite this article: Lee BR, Class HC. Cognitive outcomes in late childhood and adolescence of neonatal hypoxicischemic encephalopathy. Clinical and Experimental Pediatrics 2021;64:12608-18. https://doi.org/10.3345/cep.2021.00164 